\title{
Relîing $\mathfrak{B}$ Sefte.
}

Ŷdater $\mathfrak{B a n d}$.

Stuttgart.

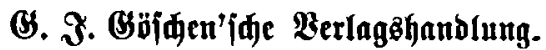

1890. 
Brud ber \$offmann'f由en Buфbruderei in Stuttgart. 